\title{
COMPARATISM AND ORGANICISM IN THE CRUCIBLE OF THE EUROPEAN JURISPRUDENCES. A JUSNATURALIST UROBOROS ON AN ENDLESS COLIMASON
}

\author{
V. CIUCĂ
}

\author{
Valerius M. Ciucă \\ Robertianum Centre for European private law, \\ Circle of Legal Hermeneutics "Școala dreptului organic" \\ "Alexandru Ioan Cuza" University of Iași \\ *Correspondence: Valerius Ciucă, Alexandru Ioan Cuza" University of Iași \\ E-mail: valerius_m_ciuca@yahoo.com
}

\section{MOTTO:}

1. Le comparatisme est véritablement analytique seulement sur le terrain fondamental des sources sapientogenes de tous les systèmes de droit (Valerius M.C.)

2. Ignea quin etiam superum pater arma recondit, / Et Ganimedeae repetens convivia mensae I Pocula sumit ea qua gessit fulmina dextra.

In memoriam Prof.dr.doc. Marțian Cotrău, son of Bihor County, an outstanding personality of Iași

Many scholars of contemporary European legal phenomena assimilate jurisprudentialism almost exclusively to common law as a family of law. There are other families of law which, directly or indirectly, establish in the jurisprudence of judges formal sources worthy of comparison with law or custom; (In which the doctrine gives it the meaning of "jurisprudential art" or Fîkîh, Fiqh, a divided art, grosso modo, on five theoretical levels: Fard, debts, Mandup, recommendations, Mubah, tacit acceptance, Makruh, Immoralities, Haram, Offenses); Also some subfamilies of traditional law systems, from societies that focus their sapiens' spirit of norms rather on the judge's mind than on the legislator's vision.

The theoretical premise that I leave is a bit different, probably because of the doctrinal "deformations" generated by cantoning too much in the sapiential space of Roman law, but also in current European law.

Pax Europaea it is a notable resultant of the beneficial comparatism in it's way of path, method, of instrument of transatlantic juridical acculturation, that succeed to achieve the great normative and institutional convergence, that generate another organic structure of the European law, fixed upon jusnaturalist principles and on the defeatism of the pre-war ultrapositivism. This happened both on nomothetic plan, and on hermeneutical one, as flashes with ardor professor René David. ${ }^{1}$ The European competition law, veritable guardian of the European peace is, totally, the best exemplum, it is an argument per se (secundum ponam casum...). Comparatism, volunteer juridical acculturation, rational and organicism are, as a rule, works of peace, of the spiral evolution status, in colimason, trying to fix the nomothetic fractures that intervenes in the history squeals.

I'll start with a categorical affirmation: what we call European Law today, that dominates the European jurisprudences, as well as the national ones that stand below the

\footnotetext{
${ }^{1}$ René David, Cours de droit privé comparé, Tome II, Ed. Les Cours de Droit, Paris, 167-1968, p. 515: "Il ne suffit pas d'avoir des lois uniformes. Encore faut-il que ces lois soient interprétées et appliquées de même façon dans les divers pays qui les ont adoptées."
} 
principle of the European primacy (Van Gend), it is a right resulted from a "refinement" of the common law nature. Practically, the judges from the Institutional European System rationalize and crystallize judicial solutions that become, after that, jurisprudences, from a modus cogitandi ac operandi way, like our Anglo-Americans brothers, but in a type a procedure and processual references copied from the French top administrative procedure (dominant in the famous Conseil d'Etat).

Let's now "inspect the troops": we have an impressive majority of judges coming from the European continental system (notable exceptions being those coming from the common law, such are the judges from United Kingdom of Great Britain and Northern Ireland, or from Ireland, as well as those coming from the mixed systems, such as: Scottish, Maltese and Cypriotes). Their proportion, among other from all $24 \mathrm{EU}$ member countries is, evidently, very low. Their professional forging to the roman-civils tradition (I'm referring to the continental judges) is, apparently, very different to those of Anglo-American culture. Just apparently, because, as a result of a constant phenomenon of institutional convergence, and one and the other succeed to come closer to the line of epistemological fracture, and even surpass it. We shall come back to this important aspect of the professional training in different juridical cultures, but with the vocation of a certain harmonious synthesis.

In our "inspection" we observe, then, some structure of the process by French administrative canons: two distinct phases of the process, named (slightly abusive, what is right) the "written phase" and, respectively, the "oral phase". The first phase it is extremely time-consuming, taking place on the diptych: action (requête, as an Court introductory act) statement defense (mémoire en defense), respectively, replica (mémoire en replique) duplica (mémoire en duplique). I always wondered, why not, triplica (mémoire en triplique)?

Here we observe a certain semantic drift, of course, with immediate practical consequences concerning: removing the judge from his role as a great supervisor of the trial, because the administration of evidence and the argument dialectics game remain outside its presence (indeed, tradition gives it primacy in the process precisely because of these qualities that make it the great master of factuality, i.e., in legal terms, of probation and of fair processuality, on an equal footing, open, visible or "public").

We record, therefore an "heresy" beside the constantinian procedure, like I called (extra ordinem sau cognitia extraordinaria generalized) ${ }^{2}$ from the Post Classic Roman Era and from the modern trial. Why? I think that, due to some superficial interpretation of the replica signification, of the duplica and triplica. These three exceptions (because of exception we are talking, or we need to talk) there aren't self-standing procedural sequences. They are elements reserved exclusively to the exception plan or, in the case of the last two (replica and triplica), exceptions to exceptions (exceptio exceptionis causa sive contraria exceptio ${ }^{3}$ ).

The whole plan of the usual dispute in the continental trial, including, let's say the exceptions too, is, thorugh a living Roman tradition (starting from exempli gratia, Fragmenta Vaticana et Collatio legum Mosaicarum et Romanorum partially recovered in Leges Romanae Barbarorum - $\mathrm{s} . \mathrm{VI}^{4}$ ), the following:

\section{Convergentia in the judicial debates structure: 1. narratio (r.)/}

\footnotetext{
${ }^{2}$ Valerius M. Ciucă, "Euronomosofia sous le parapluie du jus actionum. Les principes qui donnent la substance de l'extraordinaria cognitio, comme héritage ontologique du procès européen modern" en Fernando Reinoso Barbero (coordinador), Principios generales del Derecho. Antecedentes históricos y horizonte actual, Thomson Reuters Aranzadi, Madrid, Pamplona, 2014, pp. 1079 et sq.

${ }^{3}$ Julius Paulus, Digesta, De exceptiis, Liber XLIV. Titulus primus, apud Gaston May, Éléments de droit romain, à l'usage des étudiants des Facultés de droit, Ed. VII. Ed. Larose, Paris, 1901, p. 583, in Valerius M. Ciucă, Drept roman. Lecțiuni, Vol. I, Ed. Universității ”Al.I.Cuza" Iași, 2015, p. 132.

${ }^{4}$ G. May, op. cit., p. 581.
} 
2. contradictio (p.)/

3. postulatio $(\mathrm{r}$.

4. exceptio (nova contradictio, $p$.$) )$

5. replicatio (r.)/ (that paralyze exceptio)

6. duplicatio (p.)/ ( -"- replicatio)

7. triplicatio $(\mathrm{r}) /.($ - - duplicatio $)$.

This plan of the debates must be represented a model, beside Talmud, in the development of the dialectical elements from Accursius glosses and Bartolist comentaries, those that fundament our own methodological preoccupation inside the Juridical Hermeneutic Circle "Şcoala dreptului organic", the nucleus of Robertianum Centre of European Private Law. Briefly, this shows like follows:

"I - primum dividam (analyse du texte juridique par:

I.1 - lectura, la présentation intégrale du texte juridique;

I.2 - summa, le résumé du texte;

II - secundum ponam casum (casuistique réelle et eidétique, imaginaire, le lien immédiat entre l'abstraction du texte et la réalité conflictuelle);

III - tertium historia regulae explorabo (troisièmement, je vais examiner le premier axe de l'investigation comparatiste, l'axe verticale - Optima enim est legum interpres consuetudo , „La coutume est une excellent interprète des lois”);

IV - quartum comparabo (quatrièmement, sur l'axe horizontale du travail de comparaison, je vais inclure, dans l'analyse prospective et exploratoire, des références au texte matriciel d'Institutionum seu elementorum (Justinien) et au Code civil napoléonien, à des textes similaires contemporaines.

$\mathrm{V}$ - quintum colligam [cinquièmement, je ferai une possible exégèse du texte par:

V1 - l'analyse grammaticale - littera, comme suit:

V.1.a - vulgari usu loquendi: les notions et les locutions sont interprétées selon le sens communs;

V.1.b - ab etymologia: le sens original des concepts qu'on opère;

V.1.c - a rationis legis stricta: les significations particulières des concepts, définies, expressis verbis;

V.1.d - ab rationis legis: les significations déductibles au sein de la loi, sa logique de produire des effets juridiques;

V.1.e - pro subjecta materiae: les expressions juridiques peuvent, finalement, être interprétées téléologiquement;

V.2 - la contextualisation - sententia - qui suppose, dans une analyse excursive - expectative, des recherches de droit romain, sociologie, anthropologie, psychologie juridique;

V.3 - l'identification du sens philosophique et théologique, ainsi que du sens social et politique;

V.4 - l'identification du sens obscur - sensus -, c'est-à-dire du quatrième sens.

VI - sextum opponam et quaestio (sixièmement, je vais étudier les objections possibles au raisonnement impliqué par le texte et je vais clarifier les contradictions suivant la méthode dialectique);

VI.1 - la thèse - pro auctoritas;

VI.2 - l'antithèse - contra auctoritas;

VI.3 - la synthèse - dicta;

VII - septimum queram, brocardum et de lege ferenda [septièmement, je vais examiner les justifications du droit sanctionné par le texte respectif en exposant les arguments et les 
exceptions, y compris exceptio exceptionis causa, en respectant finalement les principes généraux, des brocarts durables"5

Finally, following our inspection, we observe the European judges at the peak of the trial, which is the deliberations phase. Well, related with Augustinian and Tomist tradition ${ }^{6}$, we link the deliberations by the idea of harmony (a substitute of the justice concept and, of course, the very substance of the justice, of the equity as a cardinal social ideal, beside freedom. Harmony is a natural connection between the real world, perceived by us and intellect, represented by us (adaequatio rei et intellectus). This what is always expected from the judge.

If, the European judges from the member states (they are called national judges but in fact they are European, in respect with the Oliver Wendell Holmes Jr. conception, he himself a judge and savant, that defines the judge through the light of the formal applied sources, not from the geographical point of view... ${ }^{7}$ ), in their praetorians invoke, invariably, the support of the law (and law' limits, of course, after the fallacious collective prejudice expressed somewhat trivially Dura lex sed lex), well, the European judge from Luxembourg invoke, in the first place, the idea of equity ${ }^{8}$, with support in the judge' reason and in jurisprudences and, with the natural scrupulosity to not transgress the letter of the law (treaties, regulations, directives etc.).

In other words, in the decisive moment of the trail, the European judge (let's call like that) is, apparently paradoxical, paralogical, a common law judge $e^{9}$ jusnaturalist (little positivist, what's right) and jurisprudencialist as in the Roman Classic Age (with tendency, often, self-referential, for the sake of equity and harmonization of the European rules $)^{10}$.

Does the European judge wanted to acquire this profile, illustrated above?

\footnotetext{
${ }^{5}$ Valerius M. Ciucă ("Preface"), Codrin Macovei, Septimiu Panainte (coordinators), Școala dreptului organic. Aplicațiile Cercului de hermeneutică juridică "Școala dreptului organic", Vol. I, Junimea Printing House, Iași, 2007, pp. 13 et sq.; explicative text, resumed circumstantially in various other works and conferences, the latter being presented at the "St. Clement" University in Sofia, at the Congress of the Romanian Society of the Balkans (Societas Jure Romano) in October 2016.

${ }^{6}$ St. Toma d'Aquino: Veritas est adaequatio rei et intellectus.

${ }^{7}$ Oliver Wendell Holmes Jr. (8. III. 1841 - 1935), a prominent, influential representative of sociological realism in American law, thinking this way: If you want to know what the judge's evening judgment looks like, look at what he ate at breakfast ...

${ }^{8}$ Valerius M. Ciucă, Euronomosofia, Vol. II, In căutarea substanței ontologice și a palingeneziei dreptului european, Academic Foundation Printing House AXIS, Iași, 2016, p. 69: " the principle of proportionality (the ancestral principle of applied wisdom, solomonics, solidity and fairness, equity - NB! It judges juridical similar relationships with the same unit of measure, and different legal relationships with different measures! -, of common reason, as in common law, a principle of judiciary excellence”. See also CJUE, Court Decision (Second Chamber), 19 July 2012, „The Sixth Directive TVA - Directive 2006/112/CE - the concept of «economic activity» - Wood supplies to cover the damage caused by a storm - Reverse change scheme - Noninclusion in the register of the taxable persons - Fine - The principle of proportionality", Case C-263/11, having as object a request for a preliminary rulling under Article 237 TFUE from the Augstākās tiesas Senāts (Latvia), made by Decision of $13^{\text {th }}$ of May 2011, received at the Court on $26^{\text {th }}$ of May 2011, in the proceedings Ainārs Rēdlihs against Valsts ienēmumu dienests, (...)

${ }^{9}$ Valerius M. Ciucă, Euronomosofia, Vol. I, Prolegomene la o operă in eșafodaj, Academic Foundation Printing House AXIS, Iași, 2012, p. 154: "... we can understand how the judge does not break the rule when he saves justice in the face of legalism. The whole jurisprudential European law makes this suppressive work of adapting norms to the requirements of reason and equity".

${ }^{10}$ R.C. van Caenegen, op.cit, pp. 38-39: " On the contrary, the Roman law of the classical period is in many respects closer in character to the English common law than to the modern civil-law systems which are derived from the medieval schools. This is because both classical Roman law, and the common law were developed through opinions and debates among experts, occasioned by particular lawsuits, rather than through general rules laid down by the legislator or theories produced by learned professors. Also in both cases legal development was centred around particular forms of action, i.e. the praetor's formula and the chancellor's writ. The modern civil law, in contrast, was based on university teaching and the academic study of the text of the Corpus iuris; it was, in other words, not case-law but book-law. The civil law is derived from post-Roman (or at least post-classical) Roman law, whereas the early common law unwittingly retraced the steps of the latter."
} 
Of course, not, or, better, not expressly, I'd dare to answer somewhat trenchant, without following a certain palinode to the principle of the non-transgression of the judge, which I referred above.

I don't want to contradict myself, but to stress, referring to an absolutely new, sometimes unusual legal situation in the post-war Europe, a reality that managed to get it out of the self-imposed "logic" of the national superbia raised to the rank of false universal criteria. Here appears the mythological figure of Uroboros: there is, sometimes, a certain dysfunction in the perfect circularity of the closed model, of the juridical "paradigm"; can he, the European judge in nuce, to believe, shortly before Robert Schuman's providential Statement in the Clock's Hall of the Palace from Quay d'Orsey, that he would soon become something other than "national judge"? In other words, can he expect a projection of the plain circularity on the spiral, on the colimason of the historical development, from a" $2 D$ " in a " $3 D$ " frame...? I'm afraid not. And so, it happened only in a century, and with the acculturation of the German Law of the Social Security, just in the liberal France or, more evidently, with the acculturation of the American Law of Competition (a "heresy" striking the sky for the liberal fundamentalism in conservative Europe or, worse, in that levelling, uniformist, crypto-slave Soviet type $)^{11}$.

As such, I believe, in adopting the new profile, more pronounced "Anglo-American", more jusnaturalist, the European Judge was constrained by the pauperisation of the new European post-war law, being for the moment clouded by the European Law of Legal Values, with all the palingenesis and its rebirths.

The same judge was constrained by the complexity of the commercial and socialeconomic "European" relationships, a complexity unmatched since the Classical and Roman Post-Classical Age, where the in double prism effect, of the transatlantic juridical divergences and convergences, did not belong to the rational expectations of the European national judges.

It was constrained, finally, and more than anything else, the rewarding and benevolent jusnaturalism, with its strong moral nucleus, with the expansion of the requirements from rational to temperament and a very good non-rational aspect, one of character and vocation, one of an evidently strong Anglo-American inspiration ${ }^{12}$ (though, through our pre-war thinkers like, for example, Simion Bărnuțiu, there were the new commands of good judicial

\footnotetext{
11 Jean Monnet, Mémoires, Librairie Arthème Fayard, 1976, Nouvelle édition, 2007, pp. 511-512: "Le problème était de briser les concentrations excessives dans la sidérurgie et les charbonnages de la Ruhr où les anciens Konzerns (Trusts, n.ns.) qui avaient fait la puissance militaire du Reich se reconstituaient tout naturellement. Les Américains, les premiers, s'y étaient attaqués depuis de longs mois. Leur philosophie économique et politique n'admettait pas les instruments ni l'exercice de la domination chez eux et chez les autres (subl.ns.). Ils exigeaient que l'organisation unique de vente du charbon allemand, le fameux Deutsche KohleVerk Gesellschaft (DKV), perdît sa structure de monopole et que les industries de l'acier ne possédassent plus les mines de charbon" (...) "C'était une innovation fondamentale en Europe, et l'importante législation antitrust qui règne sur le marché commun trouve son origine dans ces quelques lignes pour lesquelles je ne regrette pas de m'être battu quatre mois durant. Robert Bowie, une fois sa mission terminée ici, rentra aux EtatsUnis où s'étendit sa réputation universitaire. Il devint un conseiller écouté de la Maison-Blanche pour les affaires d'Europe."

12 Jan M. Broekman, A Philosophy of European Union Law, Ed. Peeters, Bruxelles, 1999, pp. 154-155: ”(...) modern law admits how non rational elements belong to expectations and that law itself has therefore no season to limit to rationality only. Paul Gewirtz once stressed this point in a fascinating essay, saying: "Myth aside, non-rational elements are central in law today. Consider just a few non-rational aspects of the self that are defining qualities of excellence in a judge: imagination, judgement, courage, compassion, good sense, energy, calmness, open-mindedness, the capacity to listen, eloquence. The American Bar Association, in rating potential judges, calls many of these qualities aspects of "temperament"; Antony Kronman would probably call them aspects of "character". My point is here that they are not usually seen as aspects of rationality, even though most of them are aspects of mind, and that these non-rational aspects of mind have long been seen as vital to the activity of judging. (Gewirtz, P.: On "I know It When I See It", in The Yale Law Journal, Vol. 105, Nr 4, 1996, p. 1033)"
} 
deontology $)^{13}$, in the process of the world-wide gigantic juridical acculturation in the postwar period, after the patent failure of positivism, often criminogenic and non-humanist, mirrored in the two "Creonian", tyrannical, abusive systems, like two downgraded daughters of Azrafil, the demon of death...

It is an illusion that the positivism removes the subjectivity of interpretation and favors the objectivity, the equidistance. On the contrary, as in the comparative law doubled by organiscism, which is based on a "controlled subjectivity", as Jean Carbonnier said, after Montesquieu $^{14}$, only admitting to subjective law its primordial role in forging the perennial and universal juridical values (idea well defended by Octavian Ionescu) ${ }^{15}$, you can trust in the good evolution of the law. I fully share this idea, supported in such a mastery way by comparator Pierre Legrand. ${ }^{16}$

\footnotetext{
${ }^{13}$ Simion Bărnuțiu, Dereptulu naturale privatu, Tiparul Tribunei Române, Iași, 1868, p. 3: "Dereptulu naturale presupune conceptele principali dein Psicologia si Antropologia: anume, cumu cà sufletulu nostru e facultatea ceea ce cugeta, sente, si voesce in noi. Dein partea facultatii cunoscitorie presupune conceptulu perceptiunii, intuitiunii, sensatiunii, alu fantasiei, alu memoriei, alu reminiscentiei, apoi alu intielesului, alu astraptiunii, reflesiunii si alu ratiunii speculative. / Dein partea facultatii sensitive presupune conceptulu sentimentului: esteticu, intieleptuale, sacru, morale, egoisticu, cordiale. / Dein partea facultatii apetitive presupune conceptulu instintului, alu arbitriului, alu vointei libere si alu ratiunii praptice. / Pretotendene in aceste trei departamente ale sufletului, ratiunea se areta cá o facultate a ideeloru, care cauta se aduca la unitate tote lucrarile nostre si se alunge contradiptiunea de pretotendine."

${ }^{14}$ Montesquieu, Scrisori persane.Caiete, Translated by Ștefan Popescu, Preface and chronology by Irina Eliade, Hyperion Printing House, Chișinău, 1993, p. XXV, in Valerius M. Ciucă, Lecții de sociologia dreptului, Polirom Printing House, 1998, p. 109:" from this angles, the rule of objectivity, as in all areas of social thinking, is in a purely "controlled subjectivity". It is the conception expressed by one of the precursors of the law sociology, Montesquieu, that, after confessing his attachement to the European states he visited for years (17281732), a manifest attachement, like that to his own country, he made, still, the effort required to any scientist to "detach himself from any trace of affectivity (exaggerated, uncontrolled subjectivity, n.m., VMC), to look at all peoples in Europe as if they were all in Madagascar".

${ }^{15}$ Octavian Ionescu, La notion de droit subjectif dans le droit privé, Préface de Georges Ripert, Seconde édition, revue et augmentée, Bruxelles, Bruylant Printing House, 1978, in integrum.
}

16 Pierre Legrand, Dreptul comparat, Lumina Lex Printing House, Bucharest, 2001, pp. 59 et sq.: "The comparison can be considered as an a priori controllable practice of producing knowledge, although it is an approach which, like all the approaches, even scientific, depends on the variations in its instruments and technical procedures, as well as the assertion imposed by the hermeneutical reflection teaches us - that, nonetheless, the comparator is not only a passive object that merely reacts to a situation. Even though the comparator does not do a job of judging, comparing it always means judging 